\title{
Systematic Review on Sanitary Pads and Female Health
}

\author{
Jingang Woo*, Soyeon Kim*, Haesoon $\mathrm{Kim}^{1}$, Kyoung Sook Jeong ${ }^{2}$, EunMee Kim ${ }^{3}$, Eunhee $\mathrm{Ha}^{4}$ \\ EwhaWomans University College of Medicine, ${ }^{1}$ Department of Pediatrics, EwhaWomans University College of Medicine, Seoul; \\ ${ }^{2}$ Department of Occupational and Environmental Medicine, Hallym University Sacred Heart Hospital, Anyang; ${ }^{3}$ Department of \\ International Studies, Graduate School of International Studies, EwhaWomans University, Seoul; ${ }^{4}$ Department of Occupational and \\ Environment Medicine, EwhaWomans University College of Medicine, Seoul, Korea
}

The majority of South Korean females use sanitary pads, which contain various organic solvents which could be excreted before and during their menstruation. However, they are not provided with findings from studies about the health effects of sanitary pads. Therefore, this study aims to establish a list of potential health hazards of sanitary pads and address the need for further extensive research by pointing out the limitations of the previous literature. A systematic review was adopted to conduct quantitative and qualitative reviews based on the PRISMA (preferred reporting items for systematic reviews and meta-analyses). Studies from electronic databases such as PubMed, RISS, and Google Scholar were retrieved for the final analyses. In accordance with our findings, we proposed a set of limitations of the previous studies. A systematic review revealed that there were effects of sanitary pads on vaginal or vulvar skin, endometriosis, and vaginal microflora. The review also revealed that organic solvents, which sanitary pads are composed of, bring potential harmful effects on pregnancy, autoimmune disease, cardiovascular disease, and neurological development. Social environments such as hygiene use or puberty education also turned out to affect female health. It was inferred that a lack of non-occupational and domestic studies reflecting the distinguishing features of sanitary pads with a reliable sample size remains as an important limitation. This study suggests that organic solvents in sanitary pads may increase some health risks bringing reproductive, autoimmune, cardiovascular, and neurological effects. Due to a lack of studies, a more extensive study can contribute to the public health of South Korean females. (Ewha Med J 2019;42(3):25-38)

\author{
Received May 6, 2019 \\ Revised July 1, 2019 \\ Accepted July 8, 2019 \\ Corresponding author \\ Eunhee $\mathrm{Ha}$ \\ Department of Occupational and Environment \\ Medicine, EwhaWomans University College of \\ Medicine, 25 Magokdong-ro 2-gil, \\ Gangseo-gu, Seoul 07804, Korea \\ Tel: 82-2-2650-5757, Fax: 82-2-2653-1086 \\ E-mail: eunheeha@ewha.ac.kr \\ *These two authors contributed equally to this \\ study as first author.
}

\section{Key Words}

Menstrual hygiene products; Menstruation; Organic solvents; Female; Social environment

\section{Introduction}

Ever since the first sanitary pad was introduced in the South Korean market in 1971, it has become a daily necessity for women going through menstruation [1]. Indispensable convenience and cleanliness due to the use of sanitary pads which facilitated females' social and daily activities promoted a quick and widespread dissemination into the South Korean market. A report conducted in 2017 by the Ministry of Food and Drug
Safety revealed that the market size of sanitary pads is about 300 billion Korean Won, taking the second place in market size among all the quasi-drugs [2]. The report also showed that $80.9 \%$ of the subjects used sanitary pads during their menstruation [2], which attested to the widespread use of sanitary pads. During the period, it was noted that approximately 21 sanitary pads were used on average [3] for every menstrual cycle. Women need to use female hygiene products including sanitary pads for a long time from their menarche at the age of 12.6 on aver-

This is an Open Access article distributed under the terms of the Creative Commons Attribution Non-Commercial License (http://creativecommons.org/licenses/by-nc/4.0) which permits unrestricted non-commercial use, distribution, and reproduction in any medium, provided the original work is properly cited. 
age [4] to their menopause at the age of 49.3 on average [5] in South Korea. In addition to this long period of application, the body part being exposed to sanitary pads requires greater attention compared to other quasi-drugs. Vulvar and vaginal tissues on which sanitary pads come into direct contact are more permeable and hydrated as well, implying the high vulnerability to chemicals and irritants when exposed to [6]. Namely, sanitary pads have three distinctive features, which are popularity, longterm use, and the vulnerability of the area applied to.

Presently available sanitary pads are mainly comprised of three parts: a fluid permeable top sheet, an absorbent core of cellulosic patch, and an impermeable back sheet. The soothing top sheet is made of a polyethylene/polypropylene fabric which is not woven. A core is a polyacrylate polymer foam while a back sheet is a polyethylene film with an adhesive. Fragrance is added between the core and the back sheet in scented pads [7]. This overall composition includes volatile organic compounds (VOCs) such as styrene, chloromethane, chloroethane, chloroform, acetone [8], which are classified as carcinogens [9], phthalates, dioxins, dioxin-like compounds, furans [10], and methyldibromo glutaronitrile (MDBGN) [7]. These VOCs have been subjects of studies in terms of safety, as their toxicity easily affects the reproductive function by hindering a precisely operating feedback system, an accurate timing and balance, and appropriate communication between cells and organs. In addition, a seemingly minor dysfunction in the reproductive system caused by their toxicity can greatly affect reproductive disorders and further pregnancy outcomes [11], implying the need for studies on the VOCs.

Indeed, there have been studies on the VOCs and the following irritation or allergic reaction accompanied by the use of sanitary pads. Several studies pointed out that the fragrance of scented sanitary pads [12] and MDBGN in the adhesive of sanitary pads are the causative agents of dermatitis [13]. Moreover, the users of sanitary pads also attribute their menstrual dysfunction such as loss of bleeding or change in the menstrual cycle [3] as well as allergic rash or irritation to sanitary pads. However, lack of related studies leaves the appeal as a complaint rather than a verifiable adverse health effect. Moreover, studies on menstrual dysfunction focus on the symptoms and the treatments or alleviation of the symptoms, without a careful examination of the potential causes of the symptoms [14]. While the potentially detrimental components of sanitary pads are mostly organic solvents [7] and specifically the volatile one (i.e., VOCs), numerous studies on organic solvents and their health effects were conducted in isolation from sanitary pads.

The purpose of this paper is to examine the health outcomes of sanitary pads impacting the users, thereby confirming the relationship between sanitary pads and their possible health hazards. Given that $45.4 \%$ of consumers are unaware of the component information [2], establishing an accurate list of the potential harms accompanied with the sanitary pads is considered to help consumers choose an appropriate hygiene product. It is also believed to encourage the policy makers to implement policies promoting proper public health in terms of sanitary pads, while socially facilitating discourses on menstruation and its devices at the same time. To achieve these goals, this paper addresses the need for further studies on a large scale regarding the direct and indirect health effects of the sanitary pads in South Korea.

This paper aims to review potentially harmful chemicals in sanitary pads and their health effects, merging individual studies hitherto in one article. The studies were reviewed with a specific focus on organic solvents in sanitary pads and their health impacts via/aside from the sanitary pads. By adopting a systematic review, both qualitative and quantitative reviews were reported based on the PRISMA (preferred reporting items for systematic reviews and meta-analyses) [15].

\section{Methods}

We searched for relevant studies by computer search from electronic databases: PubMed, RISS, and Google Scholar. We conducted searches using varied combinations of the keywords: sanitary pads, absorbent pads, organic solvents, safety assessment, sanitary products, and menstrual. 'Organic solvents' was included as a keyword as the adhering film in sanitary pads contains them which profoundly affect the health of women who are excessively exposed to them [13]. Among 1,734 records identified through database searching and 16 additional records identified through other sources, 485 duplicates were removed and 1,195 records were screened. As a result, 196 fulltext articles were assessed for eligibility and 71 studies were included in the qualitative synthesis (Fig. 1). Based on the fact that innovative features of sanitary pads were introduced since the 1970s [16], database from 1970 until 2019 was included. 


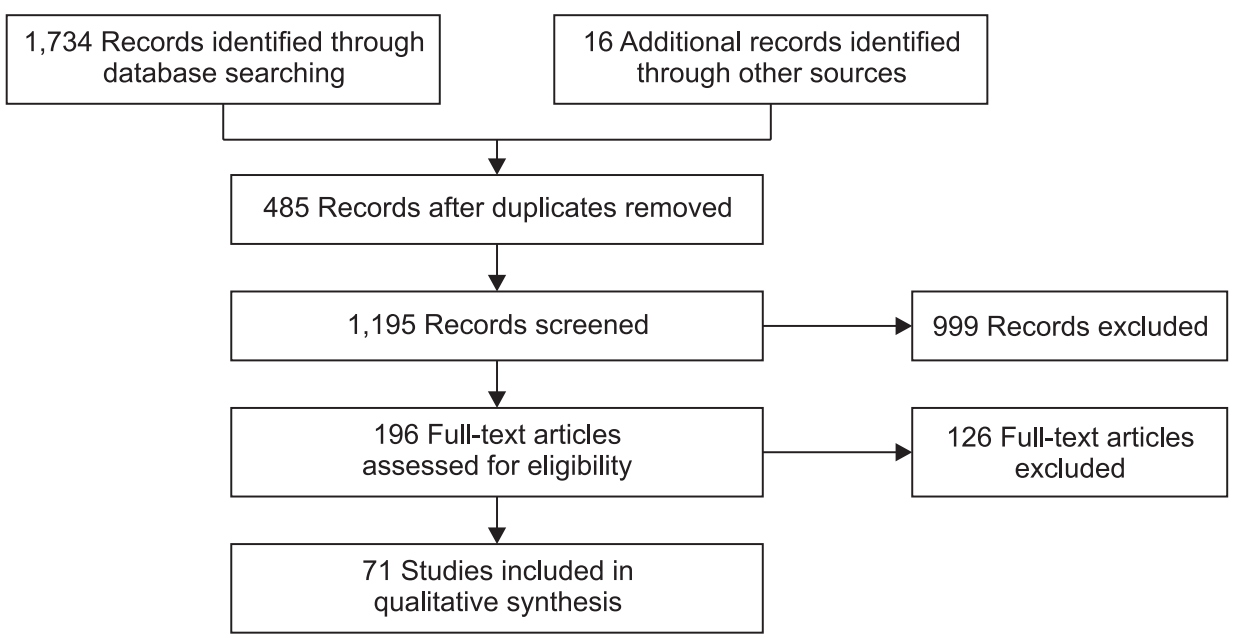

Fig. 1. The study flow table.

Animal experiments conducted on rabbits, rats, mice, monkeys, etc. and clinical studies conducted on men were excluded for precise health outcomes on human beings and women. Studies with irrelevant titles, unable to find full texts, not written in English were excluded. Studies with inadequate description of experiment methods or unclear racial backgrounds of the subjects were excluded. In addition, commentaries and Q\&As with the author of the article were excluded. Finally, among papers related to female health outcomes of organic solvents, we ruled out studies that do not include the specific types of organic solvents. Due to a relatively small number of studies, we could not exclude review articles and clinical studies of insufficient sample size. As a result, a total of 71 studies were finally reviewed in detail in this article.

\section{Results}

\section{Organic solvents in the sanitary pads}

To clarify the toxic ingredients in the sanitary pads, several state-run investigations and individual papers were reviewed. The French Agency for Food, Environmental and Occupational Health and Safety revealed a list of VOCs in the female hygiene products [17]. This includes butylphenyl methylpropional, polycyclic aromatic hydrocarbons, pesticides and di-n-octyl phthalate. Polycyclic aromatic hydrocarbon is an umbrella term for benzopyrene, benzofluorene, chrysene, cyclopentapyrene, benzofluoranthene, benzofluoranthene, benzofluoranthene, benzoperylene, benzopyrene, indenopyrene, and dibenzoanthracene. The report divided glyphosate and its metabolites such as amino- methylphosphonic acid, lindane, hexachlorobenzene, quintozene, and pentachloroaniline as pesticides. In addition to this, dioxins which include polychlorinated dibenzodioxins (PCDDs) and polychlorinated dibenzofurans (PCDFs) [18], and polychlorobiphenyls (PCBs) were detected in the sanitary towels [19]. The Swedish Chemicals Agency demonstrated that superabsorbents (sodium polycarbonate) are accompanied by their metabolites such as glycerol propoxytriacrylate, triallylamine, divinyl toluene, polyethylene glycol monoallyl ether, ethylene glycol diglycidyl or polyglycidyl ether [20]. The Ministry of Food and Drug Safety of South Korea conducted a preliminary study in 2017, finding out that 10 most harmful types of VOCs were included in 666 sanitary pads/panty liner products and 10 diaper products that were distributed in South Korea since 2014. The results revealed that although VOCs were detected in most products, it was a much lower level than the safety margin [2]. In the United States, an ingredient investigation on the widely used eight sanitary ware brands including four diaper brands concluded that all products consisted of dioxin levels even less than the amount of diet ingested [20]. Besides these, a Swiss study in 2016 also detected phthalates and formaldehydes in the sanitary towels [21]. Based on the information of the toxic ingredients, we reviewed several original studies surrounding various health effects that may be related to the usage of sanitary pads and classified them into three major parts: health outcomes, hygiene practices and educational effects, and regulatory risk assessment of sanitary pads. 


\section{Health outcomes}

Among 35 original studies retrieved for the final review in terms of the health outcomes of sanitary pads [17-51], Table 1 shows a total of 16 articles [22,26-30,33-37,39,47-50], with review articles excluded. The health outcomes provided by these studies can be classified into five subcategories: cutaneous effects, vaginal microflora, endometriosis, pregnancy, and nongestational disease.

\section{1) Direct female health outcomes of sanitary pads}

(1) Cutaneous effects of sanitary pads

Sanitary pads have direct contact with the sensitive genital skin of women. There have been some cases that raised doubts on the adverse cutaneous effects of sanitary pads, which further led to a series of studies in order to clarify the doubts. The representative case report is the case of a 49-year-old Australian nurse stricken with dermatitis surrounding her genital parts caused by MDBGN [13], which was a component of the adhesive patch of the sanitary pad she used. After she changed her pad to an eco-friendly product and began wearing inner products made of nylon and synthetic fiber cloths, she stopped complaining about those symptoms. The patching test results turned out to be positive for her sanitary pad, specifically to the adhesive part in the pad where MDBGN was used as a biocide in the manufacturing process. After this incident, the MDBGN allergy dermatitis review was carried out from 1993 to 2004 at the Skin and Cancer Foundation, Australia. The findings showed that these symptoms were quite infrequent, with only 20 cases of allergy to MDBGN being diagnosed among 2,837 patients tested during this period (0.7\%) [13]. Another study from the United States led to results implying the symptoms are not so severe. Based on self-judgement, 14 subjects with normal skin and 15 subjects with sensitive skin were selected and subjected to a randomized, double-blind trial comparing skin effects of two feminine hygiene products. No statistically conclusive differences in cutaneous resistance were found between the two groups of participants [22] (Table 1).

\section{(2) Hygiene products and vaginal microflora}

It is important for women to maintain normal microbial vaginal flora in order to prevent genital and urinary tract infections [23]. Despite deep concerns surrounding the impact of hygiene pads on vaginal microflora, hardly any study has been conducted in this category. We barely found one study showing reassuring results. It was a study held in the United States where 224 healthy female volunteers were divided into three groups: a deodorant panty liner wear group, a non-deodorant panty liner wear group, and a control group, and observed for 6 months. The results concluded that there was no statistically significant change in the frequency and density of vaginal microflora between both of the panty liner wear groups and the control group [24] (Table 1).

\section{2) Female health outcomes of organic solvents}

(1) Organic solvents and endometriosis

Endometriosis is estimated to occur in approximately $7 \%$ to $10 \%$ of reproductive-age women. It is widely known as a disease in which genetic and environmental factors act together to promote the phenotypes [25]. Many studies revealed the correlation between organic solvents and endometriosis. We found one cohort study and four case-control studies held in different countries, all assessed in a registry format. A cohort study of 495 Caucasian and Asian women held in the United States suggested that persistent organochlorine pollutants called $\gamma$-hexachlorocyclohexane were positively related to endometriosis with statistical significance [26]. In a case-control study in Italy conducted on 80 nulliparous women of reproductive age, higher levels of PCBs were found in women with endometriosis. PCB increase involved both dioxin-like (PCB 105, 118, 156, and 167) and non-dioxin-like congeners (PCB 101, 138, 153, 170, and 180) [27]. A case-control from Washington, the United States showed results that there is a positive correlation between serum concentrations of $\beta$-hexachlorocyclohexane and mirex, and endometriosis. These results raised concerns about female health effects that endometriosis may possibly be affected by broadly used organochlorine pesticides in the United States in the past or in other countries these days [28]. There was also a multinational research conducted on 22 Italian and 18 Belgian women of reproductive age, comprised of both patients and nonpatients of endometriosis. The findings showed no significant differences in dioxin-like compounds body burdens between the two groups within each country. However, there were the distant amount of body burdens between the two countries, Italian women who are known to have the highest endometriosis severity and incidence on a country basis having significantly lower results than Belgian women [29]. On the contrary, a study 
Table 1. Health outcomes surrounding sanitary products

\begin{tabular}{|c|c|c|c|c|c|c|c|}
\hline Reference & Topic & $\begin{array}{l}\text { Study } \\
\text { design }\end{array}$ & $\begin{array}{l}\text { Countryl } \\
\text { ethnicity }\end{array}$ & $\begin{array}{l}\text { Study } \\
\text { sample }\end{array}$ & $\begin{array}{c}\text { Exposure } \\
\text { assess- } \\
\text { ment }\end{array}$ & Results & $\begin{array}{l}\text { Toxins in } \\
\text { the sanitary } \\
\text { pads }\end{array}$ \\
\hline $\begin{array}{l}\text { Farage \& } \\
\text { Maibach } \\
(2007)[22]\end{array}$ & $\begin{array}{l}\text { Cutaneous effects of } \\
\text { sanitary pads }\end{array}$ & $\mathrm{CC}$ & $\begin{array}{l}\text { Caucasian, } \\
\text { Asian }\end{array}$ & 29 & Interview* & $\begin{array}{l}\text { No statistically conclusive differences in } \\
\text { cutaneous resistance were found among the } \\
\text { two group of self-judged normal skin and } \\
\text { sensitive skin participants. }\end{array}$ & $-{ }^{+}$ \\
\hline $\begin{array}{l}\text { Louis et al. } \\
\text { (2012) [26] }\end{array}$ & $\begin{array}{l}\text { Organic solvents and } \\
\text { endometriosis }\end{array}$ & $\mathrm{F}$ & $\begin{array}{l}\text { United } \\
\text { States }\end{array}$ & 495 & Registry & $\begin{array}{l}\text { Unlike other persistent organochlorine } \\
\text { pollutants, } \gamma \text {-HCH was positively associated } \\
\text { with endometriosis in a statistically significant } \\
\text { level. }\end{array}$ & Lindane [17] \\
\hline $\begin{array}{l}\text { Porpora et al. } \\
\text { (2006) [27] }\end{array}$ & $\begin{array}{l}\text { Organic solvents and } \\
\text { endometriosis }\end{array}$ & $\mathrm{CC}$ & Italy & 80 & Registry & $\begin{array}{l}\text { Women who suffered from endometriosis had } \\
\text { higher levels of PCBs, in both dioxin-like and } \\
\text { non-dioxin-like types. }\end{array}$ & PCBs [19] \\
\hline $\begin{array}{l}\text { Upson et al. } \\
(2013)[28]\end{array}$ & $\begin{array}{l}\text { Organic solvents and } \\
\text { endometriosis }\end{array}$ & $\mathrm{CC}$ & $\begin{array}{l}\text { United } \\
\text { States }\end{array}$ & 786 & Registry & $\begin{array}{l}\text { Endometriosis had a positive relationship with } \\
\text { serum concentrations of } \beta-\mathrm{HCH} \text { and mirex. }\end{array}$ & Lindane [17] \\
\hline $\begin{array}{l}\text { De Felip et al. } \\
\text { (2004) [29] }\end{array}$ & $\begin{array}{l}\text { Organic solvents and } \\
\text { endometriosis }\end{array}$ & $\mathrm{CC}$ & $\begin{array}{l}\text { Italy, } \\
\text { Belgium }\end{array}$ & 40 & Interview & $\begin{array}{l}\text { Italian women had a significantly lower } \\
\text { prevalence rate than Belgian women, who } \\
\text { are known to have the highest endometriosis } \\
\text { severity and incidence. }\end{array}$ & $\begin{array}{l}\text { cPCBs, PCBs } \\
{[19]}\end{array}$ \\
\hline $\begin{array}{l}\text { Tsukino et al. } \\
\text { (2005) [30] }\end{array}$ & $\begin{array}{l}\text { Organic solvents and } \\
\text { endometriosis }\end{array}$ & $\mathrm{CC}$ & Japan & 139 & Registry & $\begin{array}{l}\text { Endometriosis had a weak overall correlation } \\
\text { for TEQ values, with a significantly higher TEQ } \\
\text { of PCDDs. }\end{array}$ & $\begin{array}{l}\text { PCDDs, } \\
\text { PCDFs [18] } \\
\text { cPCBs, PCBs } \\
\text { [19] }\end{array}$ \\
\hline $\begin{array}{l}\text { Vaktskjold } \\
\text { et al. (2014) } \\
\text { [33] }\end{array}$ & $\begin{array}{l}\text { Organic solvents and } \\
\text { premature infants }\end{array}$ & $\mathrm{F}$ & Russia & 26,415 & Interview* & $\begin{array}{l}\text { The risk of low birth weight increased among } \\
\text { newborns in the organic solvent exposed } \\
\text { group, mainly comprising painters. }\end{array}$ & $\begin{array}{l}\text { PAH, } \\
\text { phthalates, } \\
\text { acetone, } \\
\text { xylene [21] }\end{array}$ \\
\hline $\begin{array}{l}\text { Ahmed \& } \\
\text { Jaakkola } \\
(2007)[34]\end{array}$ & $\begin{array}{l}\text { Organic solvents and } \\
\text { premature infants }\end{array}$ & $\mathrm{CC}$ & Finland & 1,670 & Interview* & $\begin{array}{l}\text { The risk of low birth rate was associated with } \\
\text { any maternal exposure to solvents } 3 \text { months } \\
\text { prior to or during pregnancy. }\end{array}$ & $\begin{array}{l}\mathrm{PAH}_{1} \\
\text { phthalates, } \\
\text { acetone, } \\
\text { xylene [21] }\end{array}$ \\
\hline $\begin{array}{l}\text { Correa et al. } \\
\text { (1996) [35] }\end{array}$ & $\begin{array}{l}\text { Organic solvents } \\
\text { and spontaneous } \\
\text { abortion }\end{array}$ & $\mathrm{CC}$ & $\begin{array}{l}\text { United } \\
\text { States }\end{array}$ & 1,150 & Interview* & $\begin{array}{l}\text { Among female manufacturers, spontaneous } \\
\text { abortion rates were increased following the } \\
\text { potential exposure of ethylene glycol ether. }\end{array}$ & $\begin{array}{l}\text { Ethylene } \\
\text { glycol ether } \\
{[20]}\end{array}$ \\
\hline $\begin{array}{l}\text { Heidam } \\
\text { (1984) [36] }\end{array}$ & $\begin{array}{l}\text { Organic solvents } \\
\text { and spontaneous } \\
\text { abortion }\end{array}$ & $\mathrm{F}$ & $\begin{array}{l}\text { Danish } \\
\text { county of } \\
\text { Fune }\end{array}$ & 5,205 & Interview* & $\begin{array}{l}\text { Only the odds ratio of jobs exposed to organic } \\
\text { solvents, which were painters and factory } \\
\text { workers, were the ratio of a significantly } \\
\text { increased level of spontaneous abortion. }\end{array}$ & $\begin{array}{l}\mathrm{PAH}, \\
\text { phthalates, } \\
\text { acetone, } \\
\text { xylene [21] }\end{array}$ \\
\hline $\begin{array}{l}\text { Vaktskjold } \\
\text { et al. (2011) } \\
\text { [37] }\end{array}$ & $\begin{array}{l}\text { Organic solvents } \\
\text { and congenital } \\
\text { malformation }\end{array}$ & $\begin{array}{l}\text { F } \\
\text { (Co- } \\
\text { hort } \\
\text { study) }\end{array}$ & Russia & 11,273 & Registry $^{+}$ & $\begin{array}{l}\text { Respectively, the adjusted odds ratios for } \\
\text { malformations of the circulatory and } \\
\text { reproductive system at birth were } 2.03 \text { and } \\
2.24 \text {. }\end{array}$ & $\begin{array}{l}\mathrm{PAH}, \\
\text { phthalates, } \\
\text { acetone, } \\
\text { xylene [21] }\end{array}$ \\
\hline $\begin{array}{l}\text { Caserta et al. } \\
\text { (2013) [39] }\end{array}$ & $\begin{array}{l}\text { Organic solvents and } \\
\text { infertility }\end{array}$ & $\mathrm{CC}$ & Italy & 61 & Interview* & $\begin{array}{l}\text { Infertile women had a higher percentage } \\
\text { of patients with detectable levels of BPA } \\
\text { concentration and mean expression of } \\
\text { receptors such as estrogen receptor } \alpha \text {. }\end{array}$ & BPA [35] \\
\hline
\end{tabular}


Table 1. Continued

\begin{tabular}{|c|c|c|c|c|c|c|c|}
\hline Reference & Topic & $\begin{array}{l}\text { Study } \\
\text { design }\end{array}$ & $\begin{array}{l}\text { Country/ } \\
\text { ethnicity }\end{array}$ & $\begin{array}{l}\text { Study } \\
\text { sample }\end{array}$ & $\begin{array}{c}\text { Exposure } \\
\text { assess- } \\
\text { ment }\end{array}$ & Results & $\begin{array}{c}\text { Toxins in } \\
\text { the sanitary } \\
\text { pads }\end{array}$ \\
\hline $\begin{array}{l}\text { Oddone et al. } \\
\text { (2013) [47] }\end{array}$ & $\begin{array}{l}\text { Organic solvents and } \\
\text { multiple sclerosis }\end{array}$ & $\mathrm{CC}$ & Italy & 1,134 & Interview* & $\begin{array}{l}\text { There was a more frequent occurrence of } \\
\text { multiple sclerosis in the organic-solvent } \\
\text { exposed occupations. }\end{array}$ & $\begin{array}{l}\mathrm{PAH}, \\
\text { phthalates, } \\
\text { acetone, } \\
\text { xylene [21] }\end{array}$ \\
\hline $\begin{array}{l}\text { Eskenazi et al. } \\
\text { (1988) [48] }\end{array}$ & $\begin{array}{l}\text { Organic solvents } \\
\text { and cardiovascular } \\
\text { diseases }\end{array}$ & $\mathrm{CC}$ & $\begin{array}{l}\text { United } \\
\text { States }\end{array}$ & 270 & Registry $^{\dagger}$ & $\begin{array}{l}\text { Women from the exposed group had more } \\
\text { cardiovascular defects and delivery by } \\
\text { cesarean section. }\end{array}$ & $\begin{array}{l}\mathrm{PAH}, \\
\text { phthalates, } \\
\text { acetone, } \\
\text { xylene [21] }\end{array}$ \\
\hline $\begin{array}{l}\text { Tikkanen \& } \\
\text { Heinonen } \\
\text { (1991) [49] }\end{array}$ & $\begin{array}{l}\text { Organic solvents } \\
\text { and cardiovascular } \\
\text { pregnancy outcomes }\end{array}$ & $\mathrm{CC}$ & Finland & 1,628 & Interview* & $\begin{array}{l}\text { Maternal exposure of the defect group (12.1\%) } \\
\text { was slightly more prevalent than the control } \\
\text { group, but without statistic conclusiveness. }\end{array}$ & $\begin{array}{l}\mathrm{PAH}, \\
\text { phthalates, } \\
\text { acetone, } \\
\text { xylene [21] }\end{array}$ \\
\hline $\begin{array}{l}\text { Eskenazi et al. } \\
\text { (1988) [50] }\end{array}$ & $\begin{array}{l}\text { Organic solvents and } \\
\text { neurodevelopmental } \\
\text { pregnancy outcomes }\end{array}$ & $\mathrm{CC}$ & $\begin{array}{l}\text { United } \\
\text { States }\end{array}$ & 82 & Interview* & $\begin{array}{l}\text { No differences in neurobehavioral development } \\
\text { or growth were caused by the relatively low } \\
\text { levels of organic solvent utero exposure in the } \\
\text { exposed group. }\end{array}$ & $\begin{array}{l}\mathrm{PAH}, \\
\text { phthalates, } \\
\text { acetone, } \\
\text { xylene [21] }\end{array}$ \\
\hline
\end{tabular}

$\mathrm{CC}$, case-control study; F, follow-up study; $\mathrm{HCH}$, hexachlorocyclohexane; $\mathrm{CPCB}$, coplanar polychlorinated biphenyl; PCB, polychlorobiphenyl; PCDD, polychlorinated dibenzodioxin; PCDF, polychlorinated dibenzofuran; TEO, toxic equivalency; PAH, polycyclic aromatic hydrocarbon; BPA, bisphenol A.

*Self-reported exposure, e.g., questionnaire. ${ }^{\dagger}$ Job title or job task. ${ }^{{ }^{*}-}{ }^{\prime}$ refers to the irrelevance of the article to the toxins or volatile organic compounds.

conducted in 2005 in Japan presented conflicting results. The experimental results of this study suggested that endometriosis of infertile Japanese women is not correlated to the serum levels of these organochlorine compounds. The study found out only a weak negative relationship for total toxic equivalency values of PCDDs, cPCBs, PCDFs, and PCBs ( $\mathrm{P}=0.06)$ [30]. Still, there are great insufficiencies on the research of endocrine disruptor chemicals (EDCs) and endometriosis. To fully study EDCs, future research should fulfill at least four goals: applying the frameworks which cover sampling of both clinic and population; employing the extensive database; conceiving novel designs to study a wide range of control groups; and devising innovative approaches of conducting experiments and statistically inducing the results [31].

\section{(2) Organic solvents and pregnancy outcomes}

There have been assumptions suggesting that the exposure of organic solvents lead to adverse pregnancy outcomes. Despite a large number of studies to validate various outcomes, epidemiologic evidence still remains equivocal [32]. We analyzed pregnancy outcomes in terms of four aspects and examined the status of each field of study.

\section{Premature infants}

In a large-scale cohort study conducted on 26,415 singleton neonates delivered in Moncegorsk, Russia, the risk of low birth weight increased among neonates in the organic solvent-exposed group (adjusted odds ratio [OR], 1.68; 95\% confidence interval [CI], 1.18 to 2.41), which are mainly comprised of painters. The adjusted odds of low birth weight in the exposed group were also higher among neonates born at full term [33]. The case-control study held in Finland led by the government showed similar results. The risk of the premature baby was correlated to any maternal exposure of solvents 3 months prior to or during pregnancy (adjusted OR, 1.67; 95\% CI, 1.02 to 2.73). Also, the adjusted $\mathrm{OR}$ for low birth weight was elevated with exposure, though it did not reach statistical significance with a small margin (adjusted OR, 1.17; 95\% CI, 0.71 to 1.93) [34] (Table 1). 


\section{Spontaneous abortion}

There was a case-control study for 1,150 pregnancies of both 561 female semiconductor manufacturing plant laborers and 589 wives of male laborers. The results showed that among female manufacturers, spontaneous abortion and subfertility increased following the potential exposure to ethylene glycol ether. On the other hand, there was no elevated risk in spontaneous abortion and subfertility among wives of male laborers [35]. In a followup study held in the Danish county of Fune, pregnancies of 5,205 women from six different occupations with exposure to organic solvents, inorganic mercury, nitrous oxide, and pesticides were examined. Consequently, the increasing ratio of spontaneous abortion was found only in occupations exposed to organic solvents, which were factory workers and painters [36] (Table 1).

\section{Congenital malformation}

A cohort study from Russia was based on 712 singleton newborns of women with occupations easily exposed to organic solvents, such as painters or spoolers, and 10,561 newborns of non-exposed mothers. Although there seemed to be a higher risk of deformity in the circulatory and reproductive system among neonates of women in occupations being easily exposed to organic solvents during early pregnancy, the results were not statistically conclusive. Respectively, the adjusted ORs for malformations of the circulatory and reproductive system at birth were 2.03 (95\% CI, 0.85 to 4.84) and 2.24 (95\% CI, 0.95 to 5.31) [37] (Table 1). A review article based on a meta-analysis in Medline also suggested that it is hard to find the correlation between congenital malformation and exposure to organic solvents during early pregnancy [38].

\section{Infertility}

Forty-eight infertile women and a control group of 13 women of healthy pregnancy outcomes participated in a study in Italy. The results were examined by the expression of nuclear receptors and the analysis of EDC serum levels of each participant. Infertile women had a higher percentage of patients with observable levels of BPA concentration than the fertile group. Moreover, infertile patients had a higher mean expression of estrogen receptor $\alpha$ and $\beta$, androgen receptor and pregnane $\mathrm{X}$ receptor compared to fertile patients [39] (Table 1). This result should not be overlooked as the female hygiene products in- cluding sanitary pads contain bisphenol [40]. A review article published in 2019 also supported this study by revealing that adult female and male reproductive functions could be interfered by exposure to various environmental contaminants including organic solvents [41]. Current research suggests that possible health defects could be affected by maternal exposure of solvents during pregnancy, but their effects still remain controversial [42]. Some studies claim that there is enough evidence for the correlation with spontaneous abortion and maternal exposure to organic solvents, but the inconsistent results do not support that congenital malformations are affected by the exposure to the VOCs [43]. Recent studies also suggest that the feminization of human development could be affected by exposure to EDC, an estrogenic chemical, thereby providing possible molecular mechanisms of estrogenic chemicals [44]. Although the recent field of study is actively discussed, there are still many methodological weaknesses that need to be solved such as the inaccuracy of data on exposures [45].

\section{(3) Other Health Effects}

Organic solvents may also affect the health system that is not directly related to the reproductive organs, and cause health disorders such as autoimmune diseases, cardiovascular diseases, and neurodevelopmental defects. There are studies suggesting that these health disorders affect pregnancy outcomes as well.

\section{Autoimmune diseases}

A review article showed the association of a number of diseases such as systemic sclerosis, multiple sclerosis, primary systemic vasculitis, and other autoimmune diseases with exposure to organic solvents [46]. A study held in Italy conducted on 227 multiple sclerosis patients and 907 controls supported this finding. Results revealed a close relationship between the occurrence of multiple sclerosis and solvent exposures, given that there was a more frequent occurrence in highly exposed occupations such as in the shoe/leather factory and mechanical manufacturing industry [47] (Table 1).

\section{Cardiovascular diseases}

There was a study in the United States on 90 women of occupational exposure and 180 women of unexposed, both in pregnancy. The women of exposed had more cardiovascular defects and were more likely to deliver by cesarean section 
[48]. A case-control in Finland implied the impact of organic solvents on the newborn. It was based on 573 mothers whose offspring had verified cardiovascular malformations, and 1,055 randomly selected controls. The outcomes showed that maternal exposure to the VOCs of the defect group (12.1\%) was slightly more prevalent than the control group (7.8\%) [49]. However, the cesarean section is commonly conducted for a variety of causes, and therefore, it is hard to find a direct relationship with solvent exposure [48]. In addition, the association was not statistically significant after adjusting the maternal age [49].

\section{Neurodevelopmental defects}

Forty-one children from the United States with maternal occupational exposure to organic solvents and a control group of the same number participated in a study conducted to examine the neurodevelopmental pregnancy outcomes of organic solvents. Results showed no differences in neurobehavioral development or growth which can be attributed to the relatively low levels of organic solvent utero exposure in the exposed group [50] (Table 1). Nonetheless, studies warned that precautionary measures are still needed in this field of occupational health considering the vulnerability of early neurodevelopment [51].

\section{Hygiene practices and educational effects}

As Table 2 shows, nine original studies were reviewed in this article to examine the hygiene practices and educational effects on female health regarding the use of sanitary pads [52-57]. The studies cover different products among the nations, different types of products among the societies, large gaps in hygiene practices, and puberty education.

Sanitary pads and their usage practices vary among ethnicities and these factors have a large effect on women's health $[8,58]$. In the study about the amount of PCDDs and PCDFs in commercialized hygiene products of each country, sanitary pads and tampons from five countries (South Korea, Japan, United States, Germany, and China) were examined. The results revealed that sufficient amounts of 1,2,3,7,8-pentachlorodibenzo-p-dioxin and 2,3,7,8-Tetrachlorodibenzo-p-dioxin to harm women's health were only found in sanitary products marketed in China, and not in the products of the other four countries [18].

The frequency of the use also differs from societies. For example, Japanese women tend to use more menstrual pads than North American or Western European women on a daily basis [58]. Similarly, the type of products preferred by women in each society varies. According to a South Korean status report on female hygiene products, the vast majority, that is, $80.9 \%$ of women were found to use sanitary pads during their menstrua-

Table 2. Hygiene practices and educational effects surrounding sanitary products

\begin{tabular}{|c|c|c|c|c|c|}
\hline Reference & Topic & $\begin{array}{l}\text { Study } \\
\text { design }\end{array}$ & Country & $\begin{array}{l}\text { Study } \\
\text { sample }\end{array}$ & Results \\
\hline $\begin{array}{l}\text { Ahn \& Kim } \\
(2008)[52]\end{array}$ & Daily usage & $\mathrm{CS}$ & South Korea & 132 & $\begin{array}{l}\text { Menstrual pad usage was related to a number of discomforts including } \\
\text { unpleasant smell, and adverse effects such as an itching feeling and } \\
\text { skin rash. }\end{array}$ \\
\hline $\begin{array}{l}\text { Shah et al. } \\
(2013)[53]\end{array}$ & $\begin{array}{l}\text { Hygiene } \\
\text { practices }\end{array}$ & $F$ & India & 164 & $\begin{array}{l}\text { Subjects who received reusable pads showed higher participation in } \\
\text { schoolwork and reduced fear in garment soiling, reporting to feel } \\
\text { more comfortable. }\end{array}$ \\
\hline $\begin{array}{l}\text { Mucherah \& } \\
\text { Thomas (2017) } \\
{[54]}\end{array}$ & $\begin{array}{l}\text { Hygiene } \\
\text { practices }\end{array}$ & $\mathrm{CS}$ & Kenya & 150 & $\begin{array}{l}\text { Subjects who had reached menarche with pads showed better } \\
\text { outcomes in school attendance, grades etc. compared to those who } \\
\text { had reached menarche without them. }\end{array}$ \\
\hline $\begin{array}{l}\text { Anand et al. } \\
(2015)[55]\end{array}$ & $\begin{array}{l}\text { Hygiene } \\
\text { practices }\end{array}$ & $\mathrm{CS}$ & India & 577,758 & $\begin{array}{l}\text { Inappropriate hygiene practices were closely related to vaginal } \\
\text { discharge and reproductive tract infections with high statistical } \\
\text { evidence, respectively. }\end{array}$ \\
\hline $\begin{array}{l}\text { Hennegan et al. } \\
(2017)[56]\end{array}$ & Education & $\mathrm{CC}$ & Uganda & 27 & $\begin{array}{l}\text { Puberty education elicited improvement in girls' confidence to openly } \\
\text { talk about menstruation, as well as additional support from teachers. }\end{array}$ \\
\hline $\begin{array}{l}\text { Mason et al. } \\
(2013)[57]\end{array}$ & Education & $\mathrm{F}$ & Kenya & 120 & $\begin{array}{l}\text { Before intervention, most of the subjects coped with menarche by } \\
\text { themselves employing unhygienic methods. }\end{array}$ \\
\hline
\end{tabular}

All of the studies in the Table 2 were conducted through interview which is a self-reported exposure such as questionnaire.

CS, cross-sectional study; F, follow-up study; CC, case-control study. 
tion period [2]. This type of usage was related to a number of discomforts including unpleasant smell, leakage, and discomfort, and adverse effects such as an itching and skin rash [52].

In addition, there are large gaps in hygiene among societies, which seems to be closely related to genital health issues. At the baseline of a follow-up intervention study held in India, as much as $90 \%$ of adolescent girls employed used worn clothes during their menstruation periods due to the absence of reusable pads. At the end of the study, those who received reusable pads showed higher participation in schoolwork and reduced fear in garment soiling, and reported to feel more comfortable [53]. A cross-sectional study of Kenya described similar psychological influences. The girls who had reached menarche with pads showed better outcomes in school attendance, grades, etc. compared to those who had reached menarche without them [54]. In a large-scale cross-sectional study conducted in India on 577,758 married women, inappropriate hygiene practices were closely related to vaginal discharge and reproductive tract infections with high statistical evidence, respectively $(\mathrm{P}<0.001)$ [55] (Table 2). There has also been a review article published, suggesting that hygiene practices could be related to the toxicshock syndrome, ulcerations, intermenstrual spotting, abnormal vaginal discharge, etc. [59].

Hopefully, these gaps can be reduced through puberty education in areas with greater unmet needs. A case-control study conducted in Uganda suggested that puberty education could elicit improvement in girls' confidence to openly talk about menstruation, as well as additional support from teachers [56]. Focus group discussions in Kenya also supported the effectiveness of school education including emotional and physical support mechanisms [57] (Table 2).

\section{Regulatory risk assessment of sanitary pads}

Regulatory classifications of feminine hygiene pads vary among countries and are regulated by different administrative organizations in each country. For example, in the United States, the Food and Drug Administration is in charge of regulation of sanitary pads; in EU, pads are regarded as "broadly applicable consumer products'; and, in South Korea, they are regulated under the guidelines of 'quasi-grugs' [60]. Regulatory organizations such as the European Chemicals Agency, scientific committees like the National Academy of Sciences, and authoritative institutions such as the World Health Organiza- tion proclaim a systematic risk assessment protocol to examine chemical safety in these products. The exposure-based quantitative risk assessment is made up of four constituents: "hazard identification, exposure characterization, risk characterization, and risk management' [7]. There have been some tests on new menstrual products, such as vaginal cups, based on this assessment approach [61]. However, in South Korea, the exposure assessment protocol has not been confirmed, which may lead to insufficiency in managing with controversy on the various effects of sanitary pads [60]. Considering its large societal cost and importance [62], there is an urgent need for supplementation of the system, including that information should be shared across countries [63] or new instruments of information should be provided by legislation [64].

\section{Discussion}

A systematic review was conducted on female hygiene products with a focus on sanitary pads and their health effects. This paper classified the articles into two major parts of the health outcomes and social environments affecting sanitary pad use. The first part can be summarized with two divisions of direct and indirect effects of the sanitary pads. The direct health outcomes include two subcategories: cutaneous effects and vaginal microflora. The indirect health outcomes include five subcategories: endometriosis, pregnancy, autoimmune disease, cardiovascular disease, and neurodevelopmental defects. Studies in the field of the first two subcategories of the direct health outcomes and the first subcategory of the indirect health outcomes did not demonstrate a clear cause-and-effect relationship between sanitary pads and symptoms. Some of the results even show conflicting findings, raising the need for further studies. On the other hand, studies have investigated that exposure to organic solvents brings hazardous effects on pregnancy in terms of delivering premature infants, spontaneous abortion and subfertility, congenital malformations, and infertility. Studies in these fields revealed a high probability of exposure leading to the symptoms. Specifically, parental exposure to organic solvents has an effect on circulatory systems and genital organs. In addition, this type of exposure exerts influence on many autoimmune diseases including multiple sclerosis, and cardiovascular diseases including complications and even malformation of newborns. While there is no clear evidence of neurological defects being caused by 
organic solvents, studies still proposed a need for precautionary approach due to the vulnerability of early brain development. In terms of the latter half, socio-psychological factors, different practices and hygiene use of the products are found to affect human health as well. This also raises a need for puberty education and management education with appropriate information. Finally, by reviewing the safety assessment of the sanitary pads in several countries, this paper found that there is no unified standard, thereby resulting in different components in the pads depending on the nations. Merging all the related studies still has failed to establish a clear-cut relationship between the sanitary pads and their health effects due to four significant limitations.

First, distinguishing features of the sanitary pads were not fully exposed in studies. Most of the studies clarifying harmful chemicals and their health effects were not specifically focused on the organic solvents emitted from the sanitary pads. Reasonable deduction of the health effects of the sanitary pads from those of respiratory or cutaneous exposures to organic solvents aside from the sanitary pads does not fully manifest the severity of the effects. Without contemplating the long-time period for each application and the prolonged periodic use from menarche to menopause, the health effects cannot be fully explained. Considering that menstruation lasts for 5.17 days on average and the average cycle length is 29.43 days [65], the amount of exposure cannot be equally valued to that of daily or occupational exposure as the cumulative effects are ignored. In addition, the amount of organic solvents being absorbed by the vulva and vagina is not the same as that by the other body areas. This is because the vaginal and vulvar mucous membranes promptly absorb chemicals without metabolizing them [6]. Moreover, while the hygiene use of sanitary pads such as the period of the replacement or washing hands before the use is also critical to the health effects [55], it is not taken into account in the studies of organic solvents and their health hazards.

Second, exposure to the harmful chemicals via sanitary pads are not occupational while most of the studies were conducted under occupational conditions. Because of the excessive specificity of the occupational conditions, studies have revealed two crucial limitations-a disparate amount of exposure and absorption of organic solvents and inadequacy to generalize the results. As mentioned earlier, the amount of exposure through the sanitary pads and the following absorption by the vagina or vulva is not the same as that of the occupational exposure and the fol- lowing respiratory or cutaneous absorption in its severity. In fact, additional occupational exposures other than harmful chemicals also affect the health of the workers under certain occupational environments. Given that the subjects of the previous studies are mostly manual workers from the painters and factory workers to the nurses [32-37] who work in three shifts, it is difficult to generalize the results and apply them to the public of which the working spectrum is much wider. Workers of those fields tend to endure more harmful conditions than others aside from exposure to hazardous chemicals, like longer working hours or higher levels of work stress [32-37]. This problem can also be attributed to a lack of samples, which are constrained to a small group due to occupational specificity.

Third, in the same vein, there is a small number of studies on the sanitary pads and their health hazards while the sample size of those studies is also small. Rather than on the sanitary pads and their potential health effects, most of the studies on female hygiene products have focused on largely two subjects: testing the safety before launching in the market [16] and toxic-shock syndrome associated with tampon use [66]. Even studies on the sanitary pads are constrained to a cutaneous health impact such as irritation or allergic rash [6,12]. No further possible health risks that can be caused by the VOCs in the sanitary pads are deeply studied. This is why most of the articles reviewed by this paper are about occupational exposure to organic solvents via the skin or respiratory organs rather than vulva or vagina. Moreover, most of the clinical studies have several hundred to a few thousand subjects $[2,8,14,17-50,52-57,59]$. On the contrary, as the Korean National Statistics Office has revealed in 2016, there are 12.8 million females in the age from 15 to 49 [67], which is analogous to the age of menarche and menopause, respectively $[4,5]$. Studies of several hundred to a few thousand subjects cannot fully represent the target samples of more than ten million females.

Finally, there are no domestic studies on the sanitary pads and the following effects on human health in South Korea. As most of the studies reviewed in this paper are conducted with foreign subjects in foreign countries outside South Korea, there are two major problems. First, each nation has different criteria and audit standards for sanitary pads. For example, sanitary pads are classified as quasi-drugs in South Korea and Japan, while they are classified as a medical instrument and industrial products in the United States and Europe, respectively [68]. In 
addition, there are specific standards for the VOCs of sanitary pads in two former countries, while the United States and $\mathrm{Eu}^{-}$ rope have no such standard in terms of the VOCs [68], leading to a different amount of toxic chemicals in sanitary pads in different countries [18]. Studying with different sanitary pads under different standards from different countries makes it difficult to validate the results in South Korea. Second, the difference in subjects depending on the nation or race is not fully examined. In South Korea, most of the females use sanitary pads [3] while most of the European-American females use the tampons during the period [69]. Moreover, there are differences between the races in the microbiome of the vagina [70] of which the balance is critical for preventing vaginal infection [71], thereby affecting their reproductive health. Studies conducted abroad cannot fully put an end to questioning the safety of domestic sanitary pads for domestic users.

Nevertheless, this study has significance for being the first study to extensively and exclusively deal with sanitary pads and their health effects. This paper has described overall health hazards affecting a wide range of the human body areas. Namely, the paper includes not only the symptoms derived from direct contact of chemicals such as irritation or cutaneous allergic reaction, but also dysfunctions of the reproductive organs, and potential hazards of neurological, cardiovascular and autoimmune diseases. This paper should be recognized for not excluding studies based on organic solvents in isolation from the sanitary pads.

At the same time, the study has the following limitations, addressing a need for further research. First, the study included basic research and only clinical studies, excluding research on animals. While the purpose of the exclusion was to strengthen scientific precision, it has limits since clinical studies of intentionally exposing the subjects to harmful chemicals cannot be conducted for ethical reasons. It can be inferred that including only clinical studies, which cannot demonstrate as much accurate contrast as animal experiments can, does not fully explain the causal relationship between the VOCs and health effects. Second, many studies reviewed in this article have a very small number of subject samples. This was inevitable as there was not a sufficient number of studies with large enough samples. To conclude, this study proposes that there is a potential correlation between sanitary pads and adverse health outcomes covering not only the vaginal areas but also other body parts distinct from direct exposure to the pads. A systematic review was held in order to identify the health effects of sanitary pads which demonstrated the limitations of the previous literature in four aspects. While there was a lack of clear evidence to support the harmfulness of the sanitary pads along with the small number of researches, there was also a lack of evidence to guarantee the safety as certain toxic VOCs were actually detected in the sanitary pads. This led us to conclude that there is an urgent need to conduct further domestic research that covers the extensive health effects of sanitary pads with a larger sample size.

The established relationship between sanitary pads and their potential health hazards has the following contribution as an essential preliminary study for the safety of sanitary pads according to a classification of preventative strategies: primary prevention, secondary prevention, and tertiary prevention. In terms of primary prevention, it would contribute to establishing stricter standards on the components of the pads, thereby reducing the general exposure to harmful chemicals via sanitary pads. Secondary prevention can be achieved by providing appropriate education on the possible health effects and management of the pads to users. This study can also contribute to tertiary prevention by facilitating social discourse on menstruation and complains derived due to it.

\section{References}

1. Shin JH, Chung MH, Park M, Ahn YG. A comparison study of the views and actual use of women's sanitary products in Korea and Japan. J Korean Soc Living Environ Sys 2007;14:110-116.

2. Ministry of Food and Drug Safety. Status report on female hygiene products and safety information. Cheongju: Ministry of Food and Drug Safety; 2017.

3. Ministry of Environment. Preliminary study of health effects of disposable sanitary pads. Sejong: Ministry of Environment; 2018.

4. Ahn JH, Lim SW, Song BS, Seo J, Lee JA, Kim DH, et al. Age at menarche in the Korean female: secular trends and relationship to adulthood body mass index. Ann Pediatr Endocrinol Metab 2013;18:60-64.

5. Park CY, Lim JY, Park HY. Age at natural menopause in Koreans: secular trends and influences thereon. Menopause 2018;25:423429.

6. Farage M, Maibach HI. The vulvar epithelium differs from the skin: implications for cutaneous testing to address topical vulvar exposures. Contact Dermatitis 2004;51:201-209.

7. Woeller KE, Hochwalt AE. Safety assessment of sanitary pads with a polymeric foam absorbent core. Regul Toxicol Pharmacol 


\section{5;73:419-424}

8. Nicole W. A question for women's health: chemicals in feminine hygiene products and personal lubricants. Environ Health Perspect 2014;122:A70-A75.

9. Agency for Toxic Substances and Disease Registry. Substance priority list. Atlanta: Agency for Toxic Substances and Disease Registry; 2019.

10. Schecter AJ, Paepke O, Marquardt S. Dioxins and dibenzofurans in American sanitary products: tampons, sanitary napkins, disposable and cloth diapers, and incontinence pads. Organohalogen Compd 1998;36:281-284.

11. Schettler T, Solomon G, Valenti M. Generations at risk: reproductive health and the environment. Cambridge: MIT Press; 2000.

12. Wujanto L, Wakelin S. Allergic contact dermatitis to colophonium in a sanitary pad-an overlooked allergen?. Contact Dermatitis 2012;66:161-162.

13. Williams JD, Frowen KE, Nixon RL. Allergic contact dermatitis from methyldibromo glutaronitrile in a sanitary pad and review of Australian clinic data. Contact Dermatitis 2007;56:164-167.

14. Joffe H, Hayes FJ. Menstrual cycle dysfunction associated with neurologic and psychiatric disorders: their treatment in adolescents. Ann N Y Acad Sci 2008;1135:219-229.

15. Moher D, Liberati A, Tetzlaff J, Altman DG; PRISMA Group. Preferred reporting items for systematic reviews and meta-analyses: the PRISMA statement. Ann Intern Med 2009;151:264-269.

16. Farage MA. A behind-the-scenes look at the safety assessment of feminine hygiene pads. Ann N Y Acad Sci 2006;1092:66-77.

17. French Agency for Food, Environmental and Occupational Health \& Safety. Opinion of the French Agency for Food, Environmental and Occupational Health \& Safety on the safety of feminine hygiene products [Internet]. Maisons-Alfort: French Agency for Food, Environmental and Occupational Health \& Safety; 2018 [cited 2019 Jul 1]. Available from: https://www.anses.fr/en/system/files/CONSO2016SA0108EN.pdf.

18. Shin JH, Ahn YG. Analysis of polychlorinated dibenzo-p-dioxins and dibenzo-furans in sanitary products of women. Text Res $J$ 2007;77:597-603.

19. Ishii S, Katagiri R, Kataoka T, Wada M, Imai S, Yamasaki K. Risk assessment study of dioxins in sanitary napkins produced in Japan. Regul Toxicol Pharmacol 2014;70:357-362.

20. Swedish Chemicals Agency. Survey of hazardous chemical substances in feminine hygiene products: A study within the government assignment on mapping hazardous chemical substances 2017-2020 [Internet]. Sundbyberg: Swedish Chemicals Agency; 2018 [cited 2019 Jul 1]. Available from: https://www. kemi.se/global/rapporter/2018/report-8-18-survey-of-hazardous-chemical-substances-in-feminine-hygiene-products.pdf.

21. Swiss Federal Food Safety and Veterinary Office. Substances chimiques présentes dans les protections hygiéniques: Evaluation des risques [Internet]. Bern: Swiss Federal Food Safety and Veterinary Office; 2016 [cited 2019 Jul 1]. Available from: https:// www.blv.admin.ch/blv/fr/home/gebrauchsgegenstaende/hygieneprodukte.html.
22. Farage MA, Maibach H. Cumulative skin irritation test of sanitary pads in sensitive skin and normal skin population. Cutan Ocul Toxicol 2007;26:37-43.

23. Zhou X, Bent SJ, Schneider MG, Davis CC, Islam MR, Forney LJ. Characterization of vaginal microbial communities in adult healthy women using cultivation-independent methods. Microbiology 2004;150(Pt 8):2565-2573.

24. Farage MA, Enane NA, Baldwin S, Berg RW. Labial and vaginal microbiology: effects of extended panty liner use. Infect Dis $\mathrm{Ob}$ stet Gynecol 1997;5:252-258.

25. Tsuchiya M, Imai H, Nakao H, Kuroda Y, Katoh T. Potential links between endocrine disrupting compounds and endometriosis. J UOEH 2003;25:307-316.

26. Buck Louis GM, Chen Z, Peterson CM, Hediger ML, Croughan MS, Sundaram R, et al. Persistent lipophilic environmental chemicals and endometriosis: the ENDO Study. Environ Health Perspect 2012;120:811-816.

27. Porpora MG, Ingelido AM, di Domenico A, Ferro A, Crobu M, Pallante D, et al. Increased levels of polychlorobiphenyls in Italian women with endometriosis. Chemosphere 2006;63:13611367.

28. Upson K, De Roos AJ, Thompson ML, Sathyanarayana S, Scholes D, Barr DB, et al. Organochlorine pesticides and risk of endometriosis: findings from a population-based case-control study. Environ Health Perspect 2013;121:1319-1324.

29. De Felip E, Porpora MG, di Domenico A, Ingelido AM, Cardelli M, Cosmi EV, et al. Dioxin-like compounds and endometriosis: a study on Italian and Belgian women of reproductive age. Toxicol Lett 2004;150:203-209.

30. Tsukino H, Hanaoka T, Sasaki H, Motoyama H, Hiroshima M, Tanaka T, et al. Associations between serum levels of selected organochlorine compounds and endometriosis in infertile Japanese women. Environ Res 2005;99:118-125.

31. Smarr MM, Kannan K, Buck Louis GM. Endocrine disrupting chemicals and endometriosis. Fertil Steril 2016;106:959-966.

32. Snijder CA, te Velde E, Roeleveld N, Burdorf A. Occupational exposure to chemical substances and time to pregnancy: a systematic review. Hum Reprod Update 2012;18:284-300.

33. Vaktskjold A, Talykova LV, Nieboer E. Low birth weight in newborns to women employed in jobs with frequent exposure to organic solvents. Int J Environ Health Res 2014;24:44-55.

34. Ahmed P, Jaakkola JJ. Exposure to organic solvents and adverse pregnancy outcomes. Hum Reprod 2007;22:2751-2757.

35. Correa A, Gray RH, Cohen R, Rothman N, Shah F, Seacat H, et al. Ethylene glycol ethers and risks of spontaneous abortion and subfertility. Am J Epidemiol 1996;143:707-717.

36. Heidam LZ. Spontaneous abortions among dental assistants, factory workers, painters, and gardening workers: a follow up study. J Epidemiol Community Health 1984;38:149-155.

37. Vaktskjold A, Talykova LV, Nieboer E. Congenital anomalies in newborns to women employed in jobs with frequent exposure to organic solvents: a register-based prospective study. $B M C$ Pregnancy Childbirth 2011;11:83. 
38. Thulstrup AM, Bonde JP. Maternal occupational exposure and risk of specific birth defects. Occup Med (Lond) 2006;56:532-543.

39. Caserta D, Bordi G, Ciardo F, Marci R, La Rocca C, Tait S, et al. The influence of endocrine disruptors in a selected population of infertile women. Gynecol Endocrinol 2013;29:444-447.

40. Renz L, Volz C, Michanowicz D, Ferrar K, Christian C, Lenzner $\mathrm{D}$, et al. A study of parabens and bisphenol A in surface water and fish brain tissue from the Greater Pittsburgh Area. Ecotoxicology 2013;22:632-641.

41. Ma Y, He X, Qi K, Wang T, Qi Y, Cui L, et al. Effects of environmental contaminants on fertility and reproductive health. J Environ Sci (China) 2019;77:210-217.

42. Taskinen HK. Effects of parental occupational exposures on spontaneous abortion and congenital malformation. Scand J Work Environ Health 1990;16:297-314.

43. Lindbohm ML. Effects of parental exposure to solvents on pregnancy outcome. J Occup Environ Med 1995;37:908-914.

44. McLachlan JA, Simpson E, Martin M. Endocrine disrupters and female reproductive health. Best Pract Res Clin Endocrinol Metab 2006;20:63-75.

45. Saillenfait AM, Robert E. Occupational exposure to organic solvents and pregnancy. Review of current epidemiologic knowledge. Rev Epidemiol Sante Publique 2000;48:374-388.

46. Barragan-Martinez C, Speck-Hernandez CA, Montoya-Ortiz G, Mantilla RD, Anaya JM, Rojas-Villarraga A. Organic solvents as risk factor for autoimmune diseases: a systematic review and meta-analysis. PLoS One 2012;7:e51506.

47. Oddone E, Scaburri A, Modonesi C, Montomoli C, Bergamaschi R, Crosignani P, et al. Multiple sclerosis and occupational exposures: results of an explorative study. G Ital Med Lav Ergon 2013;35:133-137.

48. Eskenazi B, Bracken MB, Holford TR, Grady J. Exposure to organic solvents and hypertensive disorders of pregnancy. Am J Ind Med 1988;14:177-188.

49. Tikkanen J, Heinonen OP. Maternal exposure to chemical and physical factors during pregnancy and cardiovascular malformations in the offspring. Teratology 1991;43:591-600.

50. Eskenazi B, Gaylord L, Bracken MB, Brown D. In utero exposure to organic solvents and human neurodevelopment. Dev Med Child Neurol 1988;30:492-501.

51. Julvez J, Grandjean P. Neurodevelopmental toxicity risks due to occupational exposure to industrial chemicals during pregnancy. Ind Health 2009;47:459-468.

52. Ahn SH, Kim YM. A study of the perception about menstruation and discomforts of using disposable menstrual pads. Korean J Women Health Nurs 2008;14:173-180.

53. Shah SP, Nair R, Shah PP, Modi DK, Desai SA, Desai L. Improving quality of life with new menstrual hygiene practices among adolescent tribal girls in rural Gujarat, India. Reprod Health Matters 2013;21:205-213.

54. Mucherah W, Thomas K. Reducing barriers to primary school education for girls in rural Kenya: reusable pads' intervention. Int J Adolesc Med Health 2017 Jun 17 [Epub]. https://doi. org/10.1515/ijamh-2017-0005.

55. Anand E, Singh J, Unisa S. Menstrual hygiene practices and its association with reproductive tract infections and abnormal vaginal discharge among women in India. Sex ReprodHealthc 2015;6:249-254.

56. Hennegan J, Dolan C, Steinfield L, Montgomery P. A qualitative understanding of the effects of reusable sanitary pads and puberty education: implications for future research and practice. Reprod Health 2017;14:78.

57. Mason L, Nyothach E, Alexander K, Odhiambo FO, Eleveld A, Vulule J, et al. 'We keep it secret so no one should know': a qualitative study to explore young schoolgirls attitudes and experiences with menstruation in rural western Kenya. PLoS One 2013;8:e79132.

58. Farage M, Elsner P, Maibach H. Influence of usage practices, ethnicity and climate on the skin compatibility of sanitary pads. Arch Gynecol Obstet 2007;275:415-427.

59. Reame N. Menstrual Health products, practices, and problems. Women Health 1983;8:37-51.

60. Bae J, Kwon H, Kim J. Safety evaluation of absorbent hygiene pads: a review on assessment framework and test methods. Sustainability 2018;10:4146.

61. North BB, Oldham MJ. Preclinical, clinical, and over-the-counter postmarketing experience with a new vaginal cup: menstrual collection. J Womens Health (Larchmt) 2011;20:303-311.

62. Hunt PA, Sathyanarayana S, Fowler PA, Trasande L. Female reproductive disorders, diseases, and costs of exposure to endocrine disrupting chemicals in the European union. J Clin Endocrinol Metab 2016;101:1562-1570.

63. Le Moal J, Sharpe RM, Jorgensen N, Levine H, Jurewicz J, Mendiola J, et al. Toward a multi-country monitoring system of reproductive health in the context of endocrine disrupting chemical exposure. Eur J Public Health 2016;26:76-83.

64. Gelormini A. Chemical risks. From the risk assessment to the sanitary surveillance: evolution of the instruments of the occupational health. G Ital Med Lav Ergon 201 1;33:279-281.

65. McPherson ME, Korfine L. Menstruation across time: menarche, menstrual attitudes, experiences, and behaviors. Womens Health Issues 2004;14:193-200.

66. Shands KN, Schmid GP, Dan BB, Blum D, Guidotti RJ, Hargrett NT, et al. Toxic-shock syndrome in menstruating women: association with tampon use and Staphylococcus aureus and clinical features in 52 cases. N Engl J Med 1980;303:1436-1442.

67. Korean Statistical Information Service. Population census of 2015 [Internet]. Deajeon: Statistics Korea; 2016 [cited 2019 Jul 1]. Available from: http://kosis.kr/statisticsList/statisticsListIndex. do?menuId=M_01_01\&vwcd=MT_ZTITLE\&parmTabId=M_01 _01\#SelectStatsBoxDiv.

68. Ministry of Food and Drug Safety. National survey on disposable sanitary pads. Cheongju: Ministry of Food and Drug Safety; 2017.

69. Romo LF, Berenson AB. Tampon use in adolescence: differences among European American, African American and Latina wom- 


\section{EMJ wool,etal}

en in practices, concerns, and barriers. J Pediatr Adolesc Gynecol 2012;25:328-333.

70. Ravel J, Gajer P, Abdo Z, Schneider GM, Koenig SS, McCulle SL, et al. Vaginal microbiome of reproductive-age women. Proc Natl
Acad Sci U S A 2011;108 Suppl 1:4680-7.

71. Ma B, Forney LJ, Ravel J. Vaginal microbiome: rethinking health and disease. Annu Rev Microbiol 2012;66:371-389. 